Çağrı KANDEMiR

Nedim KOŞUM

Ege Üniversitesi, Ziraat Fakültesi, Zootekni Bölümü, 35040 İzmir /Türkiye

e-posta: cagri.kandemir@ege.edu.tr

Anahtar Sözcükler:

Keçi, yapay büyütme, performans, maliyet

Key Words:

Goat, artificial rearing, performance, cost

\section{Yapay Büyütme Yöntemi Uygulanan Safkan Saanen Oğlaklarında, Farklı Süt ve Süt İkame Yemlerinin Büyüme Performansına Etkileri}

\author{
Effects of Different Milk and Milk Replacers on Growth \\ Performance in Artificial Rearing Saanen Kids
}

Alınış (Received): 03.06.2015 Kabul tarihi (Accepted): 07.08.2015

\begin{abstract}
ÖZET
alışmada, Avustralya' dan ithal edilen Saanen oğlaklarında yapay büyütme Yyöntemi uygulayarak, keçi ve inek sütlerinin, kuzu, buzağı ve oğlak süt ikame yemlerinin, büyüme performanslarına etkileri araştırılmıştır. Araştırmanın materyalini kontrol ve muamele grubu olmak üzere toplam 60 baş oğlak oluşturmuştur. Her oğlak 60 günlük olduğunda sütten kesim ağırığı alınarak denemeden çıkarılmıştır. Araştırmada 60. gün oğlak canlı ağırlıkları sırasıyla; 14.12, 13.80, 13.72, 12.73, $13.41 \mathrm{~kg}$ olarak saptanırken, grup ortalamaları arasındaki farklılıklar önemli düzeyde bulunmuştur $(P<0.05)$. Benzer şekilde deneme süresince sağlanan günlük canlı ağırlık artış ortalamaları sırasıyla; $195.39,170.35,169.93,154.26,166.53 \mathrm{gr}$ saptanmış olup ve gruplar arasındaki farklılıklar istatiksel olarak önemli bulunmuştur $(P<0.05)$. Beş farklı sıvı besin ile büyütülen oğlakların büyüme performansı özellikleri benzer bulunmuştur. Kullanılan beş sıvı besinde oğlak büyütmede kullanılabilir. Ancak yapay büyütme uygulamasında kullanılacak sıvı besin seçiminde maliyet ön plana alınarak tercih yapılmalıdır. Oğlakların büyütülmesinde kullanılacak yöntemin ve sıvı besinin seçiminde esas alınacak unsur; hayvanların sağlığını olumsuz yönde etkilemeyen, erişilebilirliği kolay olan, ekonomik ve kârlılığı göz önünde bulunduracak şekilde oğlakların büyümesini sağlamak olmalıdır.
\end{abstract}

\section{GíRiş}

Keçi, diğer ruminant türlerinin yetiştirilemediği, engebeli araziye uygun yapısal özelliklerinden, üreme ve yaşama gücü yeteneklerinden dolayı, küçük çiftçiler tarafından üretimde tercih edilen bir türdür. Ayrıca keçinin, genelde kısa boylu ve verimsiz meralar ile nadas, anız ve bitkisel üretime uygun olmayan çalılık alanları değerlendirerek et, süt, kıl ve deri gibi ürünlere dönüştürebilme yeteneği onu bazı bölgelerde emsalsiz kılmaktadır. Keçi yetiştiriciliği ağırıklı olarak 
gelişmesini tamamlayamamış olan ülkelerde, ölçeği küçük işletmelerin ya da hiç toprağa sahip olmayan üreticilerin faaliyette bulunduğu bir hayvansal üretim alanıdır. Ayrıca, günümüz şartlarında köyden şehre göç eden ve şehir kenarlarında yaşamlarını sürdüren alt gelir grubundaki kitlelerin de bir üretim etkinliğidir.

Dünyada, 2013 yılı itibariyle keçi varlığı 1.005.603.003 baş civarında (FAO, 2013), Türkiye' de ise 7.719 .874 baş keçi bulunmaktadır (TUIK 2014). Türkiye, Dünya keçi varlığının yaklaşık \% 0.79 'unu bulundururken keçi sütü üretiminin \% 2,06'ünü ve keçi eti üretiminin \% 0,9'ünü sağlamaktadır (FAO, 2012). Türkiye'de keçi türünden sağlanan et ve süt üretimi oldukça sınırlı düzeydedir. Bu durum Türkiye keçi varlığının genetik özellikleri yanında yetiştiriciliğin ekstansif yapısından kaynaklandığı bilinmektedir. Türkiye'de yaygın olarak yetiştirilen Kıl keçisinden başka, küçük popülasyonlar halinde Tiftik, Kilis, Malta (Maltız), Halep, Norduz, Honamlı, Gürcü ve Abaza gibi yerli keçiler yetiştirilmektedir. Ayrıca 1960' lı yıllarda başlayan sütçü keçi ithalatı son yıllarda oldukça hız kazanmıştır. İthal edilen Saanen ve Alpin gibi ırklar gerek saf yetiştirmek için, gerekse Kıl keçilerin ıslahı için getirilmektedir (Şengonca, 1989).

Türkiye' de gün geçtikçe girişimcilerin ilgisini çeken süt keçisi yetiştiriciliğinde oldukça önemli temel sorunlar bulunmaktadır. Türkiye, Avrupa Birliği uyum aşamasında süt keçisi işletmelerinin genel yapısı hızlı bir biçimde değişim göstermektedir. Daha önceleri kırsal alanlarda küçük ölçekli ve teknolojiden uzak olarak yapılan bu hayvancılık dalı şimdi büyük ölçekli ve son teknolojiler kullanılarak yapılmaya başlanmıştır. Bu büyük ölçekli işletmelerin en önemli sorunlarından birisi yavru mortalitesinin (ölüm oranlarının) yüksek olmasıdır. İşletmeler bu sebepten dolayı her yıl büyük zararlara uğramaktadırlar. Yavru mortalitesinin yüksek olmasının nedenlerinden biri işletmelerin doğumlarla elde ettikleri yavruları, yanlış yöntemler uygulayarak büyütmeye çalışmasıdır. Bu konu küçük ölçekli işletmelerde pek fazla sorun olmamakta, böyle işletmelerde genellikle doğal (analı) büyütme uygulanmaktadır. $\mathrm{Bu}$ yöntemde; yavruların anne ile iletişimi esastır. Illetişimi sağlayamayan hayvanların yavrularını da, hayvan varlığının az olması nedeniyle çalışanlar kolayca tespit edip gerekli müdahaleyi yaparak ölmelerine engel olurlar. Fakat büyük ölçekli işletmelerde, hayvan sayısının fazla olması nedeniyle böyle bir müdahale pek mümkün değildir. Türkiye' de yeni yeni endüstriyelleşen süt keçiciliğinin bu yönü henüz gelişememiştir. Gelişmiş ülkeler incelediğinde, doğan yavruların yapay yöntemlerle büyütülerek işletmelerinin daha kârlı hale getirildiği görülmektedir. Oğlak büyütme, işletmenin gelir elde etmesinde ana kaynaklardandır. Ayrıca oğlak büyütme, sürünün yenilenmesi ve geleceği için mutlak gereklidir. Oğlak büyütme üzerinde durulması gereken en önemli konu büyütme yönteminin doğru seçimidir. Oğlak büyütmede doğal veya yapay emzirme yöntemleri uygulanmaktadır. Büyütme yönteminin seçilmesinde oğlaklar tarafından tüketilen süt miktarı ile süt emme döneminin uzunluğu büyük önem taşımaktadır. Bu dönemde içirilecek süt miktarı ve emzirme döneminin uzunluğu, ırka, süt veya süt ürünlerinin pazarlanma koşullarına ve büyütmenin amacına göre değişmektedir (Ertuğrul, 1997).

Keçi yetiştiriciliğindeki oğlak büyütmede esas olan unsur hayvanların sağlığını ve gelişimlerini olumsuz yönde etkilemeyen, ekonomik ve kârlılığı yüksek, işletmeye uygun yöntemin seçilmesidir. Doğal büyütme; oğlaklar doğumundan sütten kesilinceye kadar olan dönemde analarıly birlikte ağıl veya merada belirlenen sürelerde birlikte bulundurmalarına dayanmaktadır. Yöntem üretici tarafından son derece kolay uygulanabilmekte ve iş gücünü azaltan bir uygulama olduğundan tercih edilmektedir. Ancak pratikte, bu uygulama hayvanların gereğinden fazla süt içmesi sorununu ortaya çıkabilmektedir. Tüketilen fazla miktardaki süt ekonomik kaybın yanı sıra, oğlaklarda ishallere de neden olabilmektedir. İshal, oğlak kayıplarında ciddi bir etmen durumundadır. İshalden kaynaklanan oğlak kayıpları bölgelere ve işletme yapısına göre değişebilmektedir. Türkiye' de yapılan saha çalışmalarında da keçi yetiştiricilerinin yoğun olarak oğlak ölümlerinden şikayet ettikleri tespit edilmiştir (Savaş, 2007, Koyuncu ve ark., 2005).

Son yıllardaki araştırmalar doğrultusunda işletme kârlılığı ve oğlakların sağlığı göz önüne alınarak oğlak büyütme yöntemleri geliştirilmeye çalışılmaktadır. Özellikle uygulama sahası bulan yapay büyütme ile oğlak yetiştirme yöntemi son yıllardaki keçi sütüne artan talebin karşılanmasında ve hayvanların sağlıklı büyütülmesinde önemli bir yere sahip olmuştur (Davis ve ark., 1998, Diken, 2005, Umberger, 2007, Uğur, 2005, Diken, ve ark., 2008, Argüello ve ark, 2007). Yapay büyütme (anasız büyütülme), oğlakları kolostrum içme dönemi başında ya da sonunda analarının yanından ayrılarak çeşitli araç ve gereçlerle (emzik, biberon) sıvı besinler verilerek insan yardımıyla büyütülmesi olarak tanımlanabilir (Kaymakçı, 2006). Doğumu izleyen ilk üç ile beş gün boyunca kolostrum verilmesi oğlağın hayatta kalabilmesi için çok önemlidir (Argüello ve ark., 2004). Daha sonra keçi sütü, inek sütü, koyun sütü ve ya farklı enerji-protein oranlı süt ikame yemleri verilerek oğlaklar büyütülebilmektedir (Galinaa, 1995; Genandoy ve ark, 2002; 
Tacchini, 2006; ). Ancak yapay büyütme yönteminin uygulamasında temel koşul; sağlıklı oğlaklar yetiştirmek ve işletme karlılığının artmasını sağlamaktır (Keskin ve Biçer, 2001; Kaymakçı, 2006; Alçiçek, 2010).

\section{MATERYAL ve YÖNTEM}

\section{Materyal}

Araştırma, Ege Üniversitesi Ziraat Fakültesi Zootekni Bölümü Koyun-Keçi Deneme Ağılında (38 27 $02 \mathrm{~K}$ - 271314 D) gerçekleştirilmiştir. Avustralya' dan ithal edilen safkan Saanen ırkı keçilerden doğmuş 60 baş oğlak ile gerçekleştirilmiştir. Bu çalışmanın hayvan materyalini 2010 yılının Ocak ayında doğan 25 baş erkek ve 35 baş dişi olmak üzere toplam 60 baş oğlak oluşturmuştur. Oğlakların büyütülmesinde keçi sütü(KS), inek sütü(IS), kuzu süt ikame yemi(K-SiY), buzağı süt ikame yemi(B-SiY) ve oğlak süt ikame
yemi(O-SiY) sıvı besin olarak kullanılmıştır. Keçi ve inek sütü besin madde içerikleri, her hafta alınan süt örneklerinin ortalaması alınarak hesaplanmıştır. Süt örneklerinin analizleri Bentley 2000 Süt Analiz Cihazı ile yapılmıştır. Keçi ve inek sütlerinin, kuzu, buzağı ve oğlak süt ikame yemlerinin besin madde içerikleri Çizelge 1'de verilmiştir.

Araştırmada, oğlakların tükettikleri sıvı besinlerin yanı sıra kaba yem olarak kuru yonca otu (KYO), buğday samanı (BS) ve pelet formda oğlak büyütme yemi (OBY) kullanılmıştır (Çizelge 2). Araştırmada kullanılan kuru yonca otu, buğday samanı ile oğlak büyütme yeminin, ham besin madde içeriklerine ait kimyasal analizleri Akyıldız (1984)'de belirtilen şekilde Weende Analiz Yöntemi kullanılarak Ege Üniversitesi Ziraat Fakültesi Zootekni Bölümü Yemler ve Hayvan Besleme Anabilim Dalı laboratuvarlarında yapılmıştır.

Çizelge 1. Keçi ve inek sütü kuzu, buzağı, oğlak süt ikame yemlerinin besin madde içerikleri. Table 1. Nutrient content of Goat and cow milk, lamb, calf, kids milk replacer.

\begin{tabular}{lccccc}
\hline Analiz & KS & iÜ & K-SiY & B-SiY & O-SiY \\
\hline Kuru Madde(\%) & 13,15 & 12,05 & - & - & - \\
Ham Protein(\%) & 3,38 & 3,65 & 22,00 & 20,05 & 23,00 \\
Ham Yağ(\%) & 4,22 & 3,00 & 22,00 & 16,00 & 25,00 \\
Laktoz(\%) & 4,55 & 4,71 & - & - & - \\
Ham Selüloz(\%) & - & - & 0,10 & 0,10 & 0,20 \\
Ham Kül(\%) & - & - & 9,00 & 9,00 & - \\
Kalsiyum(\%) & - & - & 0,80 & 0,70 & 0,95 \\
Fosfor(\%) & - & - & 0,85 & 0,85 & 0,60 \\
Lysine(\%) & - & - & 1,85 & 1,60 & - \\
Nem(\%) & - & - & 3,50 & 3,50 & - \\
Vitamin A(I.U./kg) & - & - & 40000 & 40000 & 20000 \\
Vitamin D3(I.U./kg) & - & - & 2000 & 5000 & 5000 \\
Vitamin E(mg/kg) & - & - & 300 & 300 & 50
\end{tabular}

Çizelge 2. Denemede kullanılan KYO, BS ve OBY besin madde içerikleri, (\%)Tabii halde. Table 2. Nutrient content of $K Y O, B S$ ve $O B Y$ in the experiment, (\%) Needless to form

\begin{tabular}{lccc}
\hline Besin Maddesi & Yonca Kuru Otu & Buğday Samanı & Oğlak Büyütme Yemi \\
\hline Kuru Madde & 89,90 & 89,60 & 89,56 \\
Organik Madde & 82,34 & 82,72 & 81,50 \\
Ham Protein & 18,12 & 4,06 & 18,64 \\
Ham Yağ & 1,35 & 0,86 & 5,99 \\
Ham Selüloz & 25,92 & 37,05 & 48,23 \\
Ham Kül & 7,56 & 6,88 & 8,64 \\
N'siz Öz Maddeler & 36,95 & 40,30 & 8,06 \\
Metabolik Enerji(kcal/kg) & 1768 & 1250 & 2703 \\
\hline
\end{tabular}

\section{Yöntem}

Araştırmada, oğlakların keçi sütü, inek sütü, kuzu süt ikame yemi, buzağı süt ikame yemi ve oğlak süt ikame yemi tüketme esasına dayalı beş farklı sıvı ile büyütülmesi sağlanmıştır. Keçi ve inek sütü(SiyahAlaca ırkı), makineli sağımı biten hayvanlardan hemen alınarak $38-39^{\circ} \mathrm{C}^{\prime}$ de oğlaklara verilmiştir. Özel firmalar tarafından ithal edilen kuzu, buzağı ve oğlak süt ikame yemlerinin hazırlanmasında firmaların tavsiyeleri doğrultusunda, 1 litre suyun içinde $160 \mathrm{~g}$ koyarak karışımlar hazırlanmış, oğlaklara $38-39{ }^{\circ} \mathrm{C}$ 'de verilmiştir. Oğlaklara deneme süresince aynı miktarlarda sıvı besin tükettirilmiştir. Grupların tükettikleri sıvı besin miktarı, ayrı günlerde alınan bireysel canlı ağırlığın ortalama değerinin \% 20'si olarak hesaplanmış ve oğlaklara verilmiştir. Deneme boyunca uygulanan 
emiştirme programı Çizelge 3'de verilmiştir. Oğlaklar doğumlarından sonra 3 gün boyunca analarının yanında doğum bölmelerinde $(1,8 \mathrm{~m} \times 1,2 \mathrm{~m} \times 1,2 \mathrm{~m}$ ebatlarında) bulundurulmuştur. Böylelikle oğlakların serbest şekilde kolostrum tüketmesi sağlanmıştır. Deneme başlangıcı olarak, oğlakların 4. gün yaşlarına girdikleri gün kabul edilmiştir. Oğlakların gruplara dağıtımı yapııırken gruplardaki hayvan sayısı, cinsiyet dağılımı, oğlakların doğum ve her gruptaki oğlağın toplam canlı ağırlıklarının benzer olmasına özen gösterilerek dağıtımlar yapılmıștır. 60 günlük yaşa gelen her bir oğlak tek tek başka bir bölmeye geçirilmiş, sütten kesim ağırlığı saptanmış ve deneme tamamlanmıştır. Deneme süresince bir oğlağın ayağını kırması nedeniyle denemeden(B-SiY) çıkarılmıştır.

Çizelge 3. Deneme boyunca oğlaklara uygulanan emiştirme programı.

Table 3. Suckling program of kids during the experiment period.

\begin{tabular}{cccc}
\hline Gün & Öğ̈̈n & Öğ̈̈ndeki Miktar $(\boldsymbol{g})$ & Günlük Miktar $(\boldsymbol{g})$ \\
\hline $\mathbf{1 - 3}$ & Serbest & Serbest & Serbest \\
$\mathbf{4 - 7}$ & 6 & 100 & 600 \\
$\mathbf{8 - 1 4}$ & 4 & 250 & 1000 \\
$\mathbf{1 5 - 2 1}$ & 3 & 350 & 1050 \\
$\mathbf{2 2 - 2 8}$ & 3 & 400 & 1200 \\
$\mathbf{2 9 - 4 0}$ & 2 & 700 & 1400 \\
$\mathbf{4 1 - 4 8}$ & 2 & 750 & 1500 \\
$\mathbf{4 9 - 6 0}$ & 2 & 800 & 1600 \\
\hline
\end{tabular}

Denemenin yürütüldüğü oğlak büyütme bölmelerinde, oğlaklar sütten kesime kadar $6^{\prime}$ şar başlık gruplar halinde barındırılmışlardır. Her muamelede $6^{\prime}$ şar başlık 2 grup, toplamda 12 baş hayvan bulunmaktadır. Oğlak bölmeleri, 2,2m x 1,5m x 1m ebatlarında, üst, yan ve arka kısımları tamamen kapalı, ön kısmı ise açılıp kapanabilen şeffaf branda ile çevrilmiştir. Oğlak bölmelerinin her birinde üst tarafından sarkıtılan infrared $250 \mathrm{~W}$ ısıtıcı bulundurulmuştur. Bölmelerin bulunduğu zemin beton olması sebebiyle oğlakların büyütülmesinde altlıklı yetiştirme sistemi uygulanmıştır. Oğlakların altında sürekli olarak kuru ve temiz altık (buğday sapı) bulundurulmuştur. Deneme boyunca oğlak bölmelerinde pelet formda oğlak büyütme yemi, yarı yarıya karıştırıımış ve kıyılmış formda saman ve kuru yonca otu, temiz su ve mineral yalama taşı ad lib. (serbest) olarak verilmiştir. Denemede kullanılan oğlak büyütme yemi ve kuru ot karışımı ayrı ayrı yemliklerde verilmiş ve grup bazında günlük tüketim miktarları tespit edilmiştir. Tartımlar, deneme boyunca elektronik $\pm 1 \mathrm{~g}$ hassasiyette kantar ile bireysel olarak yapıımıştır.

Büyütme maliyetinin ekonomik analizinde, işletmenin özel bir firmaya günlük çiğ keçi sütü olarak satış yaptığı değer olan 1,3 TL/It ve Ege Üniversitesi Ziraat
Fakültesi Süt Teknolojisi Bölümüne günlük çiğ inek sütü olarak satış yaptığı değer olan $0,65 \mathrm{TL} / \mathrm{lt}$ baz alınarak hesaplamalar yapılmıştır. Ayrıca özel firmalardan temin edilen kuzu süt ikame yemi 1,0 TL/lt' den, buzağı süt ikame yemi $0,9 \mathrm{TL} / \mathrm{tt}^{\prime}$ den ve oğlak süt ikame yemi 0,95 TL/lt' den baz alınarak hesaplamalar yapılmıştır. Oğlakların beslenmesinde kullanılan oğlak büyütme yemi $0,75 \mathrm{TL} / \mathrm{kg}$, saman $0,35 \mathrm{TL} / \mathrm{lt}$, kuru yonca otu $0,65 \mathrm{TL} / \mathrm{lt}$ olarak kabul edilmiştir. İşletme içinde kullanılan şebeke suyu 0,003 TL/lt ve elektrik enerjisi $0,18 \mathrm{TL} / \mathrm{kWh}$ olacak şekilde fiyatlandırılarak ekonomik analizde hesaplamalar yapılmıştır.

Oğlaklar, 60 günlük deneme süresince 15 günlük aralıklarla dört kez tartılmış ve $15^{\prime}$ er günlük arayla canlı ağırlıklar tespit edilmiştir (Koşum ve ark. 2003). Her bir oğlağa ilişkin canlı ağırlık değerleri deneme boyunca elektronik kantar $( \pm 10 \mathrm{~g})$ aracılığı ile yapılan tartım yoluyla tayin edilmiştir. 15 günlük arayla yapılan tartımlarla oğlakların deneme boyunca farklı dönemlerindeki günlük ortalama canlı ağırlık artışları (GCAA) hesaplanmıştır. Kaba ve kesif yem tüketim miktarları, her sabah yeni yemlerin konulması ve ertesi sabah kalan yemlerin tartılmasıyla tespit edilmiştir. Yem tüketim değerleri, gruplar bazında alınmış ortalama alınarak bireyselleştirilmiştir.

Oğlakların canlı ağırlığına ait verilerin istatistiksel analizinde tekrarlanan ölçümlü deneme düzenlerinde kovaryans analizi (Repeated Measurement Design in Covariance Analysis) kullanılmıştır (Gürbüz ve ark., 2003). Günlük canlı ağılık artışlarına ait verilerin analizinde tesadüf parselleri deneme tertibinde faktöriyel düzende varyans analizi (Completely Randomized Factorial Experimental Design) tekniğinden yararlanılmıştır. Illgili analizlerde, farklı sıvı besinler (muamele grubu) ve oğlakların cinsiyetleri sabit etkiler (fixed effect), oğlakların doğum, 15. gün, 30. gün, 45. gün ve sütten kesim ağırlıkları kovaryant etkiler olarak alınmıştır. Verilerin analizinde (SPSS, 2007) istatistik paket programı kullanılmıştır. Analiz sırasında kullanılan doğrusal istatistik model aşağıdaki şekildedir;

$$
Y i j k=\mu+m i+c j+(m \times c) i j+e i j k
$$

Yijk = incelenen ölçüte ilişkin gözlem değeri

$\boldsymbol{\mu}=$ genel ortalama

mi = i'nci muamelenin etkisi(Sıvı Besin)

cj $=$ j'inci cinsiyetin etkisi

$(\mathbf{m} \times \mathbf{c}) \mathbf{i j}=$ muamele $\mathbf{x}$ cinsiyet interaksiyonunun etkisi eijk = hata 


\section{BULGULAR}

Araştırma kapsamında oğlakların tükettikleri ve yemliklerde kalan yemler her gün yapılan tartımlar sonucu belirlenmiş, haftalar itibariyle grup bazında hayvan başına ortalama günlük kaba ve kesif yem tüketim değerleri hesaplanmıştır. Kontrol ve deneme gruplarının kuru yonca otu ve buğday samanı karışımının $15^{\prime}$ şer günlük periyotlar halinde tüketim miktarları Çizelge 4'de verilmiştir. Keçi ve inek sütü gruplarının kuru ot tüketimleri, süt ikame yemi gruplarına göre daha fazladır.

Kontrol ve deneme gruplarında haftalık periyotlar halinde kesif yem tüketim miktarları Çizelge $5^{\prime}$ de verilmiş̧ir. Süt ikame yemi grubunda kesif yem tüketimleri, keçi ve inek sütü gruplarına göre daha azdır. En düşük kesif yem tüketimi B - SiY grubunda saptanmıştır.

Keçi ve inek sütlerinin, kuzu, buzağı ve oğlak süt ikame yemlerinin tükettirilerek büyütülen oğlaklar için sütten kesim günü canlı ağırlıkları ortalamaları sırasıyla; $14.12,13.80,13.72,12.73$ ve 13.41 olarak saptanmıştır. Ayrıca erkek ve dişi oğlakların sütten kesim günü canlı ağırlıkları ortalamaları; 13.89, 13.23 olarak saptanmıştır. Gruplar için canlı ağırlıklara ait en küçük kareler ortalamaları ve ortalamanın standart hataları Çizelge 6'da verilmiştir.

Çizelge 4. Kontrol ve deneme gruplarının haftalık kaba yem tüketim miktarları (g). Table 4. Weekly consumption of forage control and experimental group (g).

\begin{tabular}{c|cccccc}
\hline Dönemler & KS (Kontrol) & is & K-siY & B-SiY & O-siY & Önemlilik \\
\hline 0. - 15. Gün & $10,5 \pm 1,33$ & $10,7 \pm 1,21$ & $8,9 \pm 1,01$ & $7,6 \pm 1,30$ & $6,7 \pm 1,41$ & Ö.D. \\
15. - 30. Gün & $24,7 \pm 1,2^{\mathrm{a}}$ & $26,0 \pm 1,43^{\mathrm{a}}$ & $16,5 \pm 1,23^{\mathrm{b}}$ & $19,7 \pm 1,33^{\mathrm{b}}$ & $17,9 \pm 1,98^{\mathrm{b}}$ & $*$ \\
30. - 45. Gün & $50,0 \pm 3,41^{\mathrm{a}}$ & $52,7 \pm 3,61^{\mathrm{a}}$ & $32,8 \pm 2,05^{\mathrm{b}}$ & $41,1 \pm 2,74^{\mathrm{b}}$ & $38,5 \pm 2,55^{\mathrm{b}}$ & $*$ \\
45. - 60. Gün & $77,4 \pm 3,82^{\mathrm{a}}$ & $75,2 \pm 2,11^{\mathrm{a}}$ & $54,0 \pm 2,42^{\mathrm{b}}$ & $54,3 \pm 3,65^{\mathrm{b}}$ & $52,8 \pm 2,77^{\mathrm{b}}$ & $*$ \\
\hline 0. - 60. Gün & $40,7 \pm 2,7^{\mathrm{a}}$ & $41,2 \pm 2,42^{\mathrm{a}}$ & $28,1 \pm 1,83^{\mathrm{b}}$ & $30,8 \pm 2,62^{\mathrm{b}}$ & $29,0 \pm 2,15^{\mathrm{b}}$ & $*$ \\
\hline
\end{tabular}

*: $P<0.05,{ }^{*}: P<0.01$, Ö.D. $=$ Önemli Değil

$a, b ;$ Aynı satırda farklı harf taşıyan ortalamalar arasındaki fark istatistik olarak önemlidir $(P<0.05)$

Çizelge 5. Kontrol ve deneme gruplarının haftalık kesif yem tüketim miktarları (g).

Table 5. Weekly consumption of concentrated feed control and experimental group ( $g$ ).

\begin{tabular}{l|cccccc}
\hline \multicolumn{1}{c|}{ Dönemler } & KS (Kontrol) & is & K-SiY & B-SiY & O-SiY & Önemlilik \\
\hline 0. - 15. Gün & $21,5 \pm 2,16$ & $22,4 \pm 1,01$ & $13,1 \pm 1,16$ & $12,4 \pm 1,96$ & $11,5 \pm 1,47$ & Ö.D. \\
15. - 30. Gün & $45,1 \pm 1,87^{\mathrm{a}}$ & $45,1 \pm 1,45^{\mathrm{a}}$ & $32,7 \pm 1,93^{\mathrm{b}}$ & $27,7 \pm 1,65^{\mathrm{b}}$ & $27,5 \pm 1,75^{\mathrm{b}}$ & $*$ \\
30. - 45. Gün & $64,2 \pm 2,22^{\mathrm{a}}$ & $66,5 \pm 2,43^{\mathrm{a}}$ & $54,1 \pm 2,45^{\mathrm{b}}$ & $50,5 \pm 2,30^{\mathrm{b}}$ & $55,0 \pm 2,76^{\mathrm{b}}$ & $*$ \\
45. - 60. Gün & $157,2 \pm 2,5^{\mathrm{a}}$ & $163,6 \pm 3,23^{\mathrm{a}}$ & $86,4 \pm 2,80^{\mathrm{b}}$ & $84,8 \pm 1,80^{\mathrm{b}}$ & $88,5 \pm 3,21^{\mathrm{b}}$ & $*$ \\
\hline 0. - 60. Gün & $72,5 \pm 1,83^{\mathrm{a}}$ & $73,7 \pm 2,46^{\mathrm{a}}$ & $46,6 \pm 2,78^{\mathrm{b}}$ & $43,8 \pm 2,65^{\mathrm{b}}$ & $45,6 \pm 2,19^{\mathrm{b}}$ & $*$ \\
\hline
\end{tabular}

*: $P<0.05, * *: P<0.01$, Ö.D. $=$ Önemli Değil

a,b; Aynı satırda farklı harf taşıyan ortalamalar arasındaki fark istatistik olarak önemlidir $(P<0.05)$

Çizelge 6. Gruplara ait canlı ağırlıkların en küçük kareler ortalamaları ve standart hataları $(\mathrm{kg})$ Table 6. Least-squares means and standard errors of the groups of body weight $(\mathrm{kg})$

\begin{tabular}{|c|c|c|c|c|c|}
\hline \multirow{2}{*}{ Grup } & $\mathbf{n}$ & 15. Gün CA & 30.Gün CA & 45. Gün CA & 60.Gün CA \\
\hline & 59 & $x \pm S x$ & $x \pm S x$ & $\mathrm{x} \pm \mathrm{Sx}$ & $x \pm S x$ \\
\hline Keçi Sütü & 12 & $5,52 \pm 0,169 a$ & $8,31 \pm 0,222^{a}$ & $11,48 \pm 0,318^{a}$ & $14,12 \pm 0,420^{a}$ \\
\hline İnek Sütü & 12 & $4,49 \pm 0,170^{b}$ & $7,81 \pm 0,223^{a}$ & $10,87 \pm 0,318^{a}$ & $13,80 \pm 0,421 a$ \\
\hline K - siY & 12 & $5,53 \pm 0,168^{a}$ & $7,59 \pm 0,221^{b}$ & $10,57 \pm 0,316^{b}$ & $13,72 \pm 0,417^{a}$ \\
\hline B - siY & 11 & $5,07 \pm 0,175^{a}$ & $6,99 \pm 0,230^{b}$ & $9,86 \pm 0,328^{b}$ & $12,73 \pm 0,434^{b}$ \\
\hline O - siY & 12 & $5,11 \pm 0,170^{a}$ & $6,97 \pm 0,223^{b}$ & $10,04 \pm 0,318^{b}$ & $13,41 \pm 0,421^{a}$ \\
\hline \multicolumn{2}{|c|}{$P>0.05$} & $*(P=0,03)$ & $* *(P=0,00)$ & $* *(P=0,00)$ & $*(P=0,02)$ \\
\hline \multirow{2}{*}{ Eşey } & $\mathbf{n}$ & 15. Gün CA & 30.Gün CA & 45. Gün CA & 60.Gün CA \\
\hline & 59 & $x \pm S x$ & $x \pm S x$ & $x \pm S x$ & $x \pm S x$ \\
\hline Erkek & 25 & $5,28 \pm 0,122$ & $7,84 \pm 0,160$ & $10,84 \pm 0,229$ & $13,89 \pm 0,303$ \\
\hline Dişi & 34 & $5,14 \pm 0,103$ & $7,23 \pm 0,136$ & $10,29 \pm 0,194$ & $13,23 \pm 0,256$ \\
\hline \multicolumn{2}{|c|}{$P>0.05$} & Ö.D. & $* *(P=0,00)$ & Ö.D. & Ö.D. \\
\hline
\end{tabular}

*: $P<0.05, * *: P<0.01$, Ö.D. $=$ Önemli Değil

a,b; Aynı sütunda farklı harf taşıyan ortalamalar arasındaki fark istatistik olarak önemlidir $(\mathrm{P}<0.05)$ 
Oğlakların gelişme dönemlerine ait canlı ağırlık ortalamaları bakımından gruplar arasındaki farklılığın 15., 30., 45. ve 60.gün önemli $(P<0.05)$ olduğu belirlenmiştir. Buzağı süt ikame yemi ile büyütülen oğlakların canlı ağırlık ortalaması sütten kesim döneminde diğer gruplara göre daha düşük gözlenmiş ve bu fark istatiksel yönden önemli bulunmuştur $(P<0.05)$. Eşeye göre canlı ağırlıkların değişimi dönemlere göre bulunsa da, sütten kesim döneminde bu fark kapanmış ve ortalama canlı ağırlıkların arasındaki fark önemsiz bulunmuştur Ancak eşeyler arasındaki farklıı̆ın ise sadece 15. günlük yaşta önemli $(P<0.05)$ diğer yaş dönemlerinde ise önemsiz ( $P>0.05$ ) olduğu saptanmıştır.

Keçi ve inek sütlerinin, kuzu, buzağı ve oğlak süt ikame yemleri verilerek büyütülen oğlaklar için doğum ile on beşinci günler arası canlı ağırlık artış ortalamaları sırasıyla; $131.33 \mathrm{~g}, 111.61 \mathrm{~g}, 112,75 \mathrm{~g}, 122.86 \mathrm{~g}$ ve $110.30 \mathrm{~g}$ ' dır. On beşinci ile otuzuncu günler arası canlı ağırlık artış ortalamaları sırasıyla; $177.78 \mathrm{~g}, 179.17 \mathrm{~g}$, $162.92 \mathrm{~g}, 119.47 \mathrm{~g}$ ve $144.57 \mathrm{~g}$ dır. Otuzuncu ile kırk beşinci günler arası canlı ağırlık artış ortalamaları sırasıyla; 219.45 g, 199.73 g, 212.50 g, $182.42 \mathrm{~g}$ ve 205.82 g' dır. Kırk beşinci ile altmışıncı günler arası canlı ağırlık artış ortalamaları sırasıyla; $166.27 \mathrm{~g}, 187.94$ g, 206.47 g, 202.01 g, 210.47 g' dir. Ayrica erkek ve dişi oğlakların 0.-15.,15.-30.,30.-45. ve 45.-60. günler canlı ağılık artışlarının ortalamaları; 112.62 g-122.92 g, $167.66 \mathrm{~g}-145.92 \mathrm{~g}, 204.03 \mathrm{~g}-203.94 \mathrm{~g}, 200.13 \mathrm{~g}-$ $189.14 \mathrm{~g}$ olarak saptanmıştır. Grupları için günlük canlı ağırlık artışların ait en küçük kareler ortalamaları ve ortalamanın standart hataları Çizelge 7'de verilmiştir.

\begin{tabular}{|c|c|c|c|c|c|}
\hline \multirow{2}{*}{ Grup } & $n$ & 0-15. Gün CAA & 15-30.Gün CAA & 30-45. Gün CAA & 45-60.Gün CAA \\
\hline & 59 & $\mathrm{x} \pm \mathrm{Sx}$ & $\mathrm{x} \pm \mathrm{Sx}$ & $\mathrm{x} \pm \mathrm{Sx}$ & $\mathrm{x} \pm \mathrm{Sx}$ \\
\hline Keçi Sütü & 12 & $131,33 \pm 11,301$ & $177,78 \pm 14,720^{a}$ & $219,45 \pm 12,374^{a}$ & $166,27 \pm 15,048^{a}$ \\
\hline İnek Sütü & 12 & $111,61 \pm 11,301$ & $179,17 \pm 14,720^{a}$ & $199,73 \pm 12,374$ & $187,94 \pm 15,048$ \\
\hline K - siY & 12 & $112,75 \pm 11,201$ & $162,92 \pm 14,590^{a}$ & $212,50 \pm 12,265$ & $206,47 \pm 14,915$ \\
\hline B - siY & 11 & $122,86 \pm 11,674$ & $119,47 \pm 15,205^{b}$ & $182,42 \pm 12,783^{b}$ & $202,01 \pm 15,544$ \\
\hline O - siy & 12 & $110,30 \pm 11,201$ & $144,57 \pm 14,590^{a}$ & $205,82 \pm 12,265$ & $210,47 \pm 14,915^{b}$ \\
\hline \multicolumn{2}{|l|}{$P>0.05$} & Ö.D. & ${ }^{*}(P=0,035)$ & $*(P=0,04)$ & $*(P=0,04)$ \\
\hline \multirow{2}{*}{ Eşey } & $\mathbf{n}$ & 0-15. Gün CAA & 15-30.Gün CAA & 30-45. Gün CAA & 45-60.Gün CAA \\
\hline & 59 & $x \pm S x$ & $x \pm S x$ & $x \pm S x$ & $x \pm S x$ \\
\hline Erkek & 25 & $112,62 \pm 7,817$ & $167,66 \pm 10,182$ & $204,03 \pm 8,559$ & $200,13 \pm 10,409$ \\
\hline Dişi & 34 & $122,92 \pm 6,692$ & $145,92 \pm 8,717$ & $203,94 \pm 7,328$ & $189,14 \pm 8,911$ \\
\hline$P>0.05$ & & Ö.D. & Ö.D. & Ö.D. & Ö.D. \\
\hline
\end{tabular}

*: P>0.05, **: P>0.01 Ö.D.= Önemli Değil

Aynı sütunda farklı harf taşıyan ortalamalar arasındaki fark istatistik olarak önemlidir(P>0.05)

\section{Oğlak büyütmede ekonomik analiz}

Yapılan araştırmada kullanılan emiştirme programı tüm gruplarda oğlak başına tüketilen sıvı besin miktar 90 litre olarak saptanmıştır. Oğlak başı sıvı besin maliyeti bu miktara göre hesaplanmıştır. Grupların sırasıyla oğlak başı Sıvı besin maliyeti; 117 TL, 59 TL, 90 TL, 86 TL ve $81 \mathrm{TL}$ olarak bulunmuştur. Grupların sırasıyla kg canlı ağırlık başına maliyeti ise 7.75 TL, 4.28 TL 6,66 TL, 6,23 TL ve 6,38 TL olarak hesaplanmıştır.

Araştırmada, grupların sırasıyla 60 günlük büyütme dönemi boyunca tükettikleri kesif yem miktarı sırasıyla; 4,0 kg, 4,1 kg, 2,7 kg, 1,8 kg ve 2,5 kg olduğu tespit edilmiştir. Kesif yem tüketiminin maliyet hesabı yapıldığında sırasıyla; 3,00 TL, 3,08 TL, 2,03 TL, 1,35 TL ve 1,88 TL'dir. Büyütme dönemi kaba yem tüketimi incelendiğinde sırasıyla; $2,3 \mathrm{~kg}, 2,3 \mathrm{~kg}, 1,9 \mathrm{~kg}, 1,7 \mathrm{~kg}$ ve $1,6 \mathrm{~kg}$ olduğu tespit edilmiştir. Maliyet hesaplaması yapılırken kıyılmış yonca kuru otu ve saman yarı yarıya karıştııılığı için kuru ot fiyatı $0,45 \mathrm{TL} / \mathrm{kg}$ olarak kabul edilmiş ve hesaplamalar bu şekilde yapılmıştır. Grupların oğlak başına kaba yem maliyeti sırasıyla; 1,04 TL, 1,04 TL, 0,86 TL, 0,77 TL ve 0,72 TL olarak hesaplanmıştır(Çizelge 8).

Araştırma süresi boyunca işletmede, büyük oranda aydınlatma ve ayrıca ısıtma için kullanılan elektrik enerjisi miktarı $1333 \mathrm{kWh}$ olarak tespit edilmiş ve maliyeti 240 TL olarak hesaplanmıştır. Deneme süresi boyunca süt ikame yemlerinin hazırlanmasında ve büyük oranda ekipmanların yıkanmasında kullanılan şebeke suyu miktarı ise 20 ton olarak tespit edilmiş ve maliyeti $60 \mathrm{TL}$ olarak hesaplanmıştır. Deneme oğlaklarına, eksikliği görülürse çeşitli hastalıklara neden olacak vitamin ve mineral madde ihtiyacını karşılamak için bazı uygulamalar yapılmıştır. Bu uygulamaların maliyeti ve ayrıca antibiyotik içeren sprey ve enteretoksemi aşısı gibi ilaç ve aşı giderleri de toplu şekilde 
verilmiştir. Birim oğlak başına elektrik, su, yalama taşı ve ilaç masraflarının maliyeti denemedeki oğlak sayısı olan 60' a bölünerek bulunmuştur(Çizelge 8 ).

Keçi sütü (kontrol) grubu oğlak başı toplam büyütme dönemi maliyeti 131,14 TL olarak hesaplanmıştır. İnek sütü ile büyütülen oğlaklarda, oğlak başı toplam büyütme dönemi maliyeti 72,66 TL olarak hesaplanmıştır. Süt ikame yemi verilerek büyütülen deneme gruplarında kuzu, buzağı ve oğlak yemleri grupları oğlak başı toplam büyütme dönemi maliyeti sırasıyla; 102,96 TL, 93,19 TL ve 98,17 TL olarak hesaplanmıştır (Çizelge 8).

Çizelge 8. Kontrol ve deneme gruplarında büyütme maliyeti.

Table 8. The cost of enlargement in the control and experimental groups.

\begin{tabular}{|c|c|c|c|c|c|}
\hline & Keçi Sütü & Inek Sütü & Kuzu SiY & Buzağı SiY & Oğlak SiY \\
\hline Oğlak Başı Sıvı Maliyeti (TL) & 117,11 & 58,55 & 90,08 & 81,08 & 85,58 \\
\hline Tüketilen Kesif Yem Miktarı(kg) & 4,0 & 4,1 & 2,7 & 1,8 & 2,5 \\
\hline Kesif Yem Maliyeti (TL) & 3,00 & 3,08 & 2,03 & 1,35 & 1,88 \\
\hline Tüketilen Kuru Ot Miktarı (kg) & 2,3 & 2,3 & 1,9 & 1,7 & 1,6 \\
\hline Kuru Ot Maliyeti (TL) & 1,04 & 1,04 & 0,86 & 0,77 & 1,72 \\
\hline TOPLAM(TL) & 121,14 & 62,66 & 92,96 & 83,19 & 88,17 \\
\hline Elektrik, Su ve Illaç vb. gibi Maliyetler (TL) & 10,00 & 10,00 & 10,00 & 10,00 & 10,00 \\
\hline GENEL TOPLAM(TL) & 131,14 & 72,66 & 102,96 & 93,19 & 98,17 \\
\hline
\end{tabular}

Araştırmadaki büyütmenin ekonomik analizinde, en yüksek maliyete sahip oğlaklar kontrol grubu olan keçi sütünü tüketen gruptur. Daha sonra kuzu SiY, oğlak SiY ve buzağı SiY grupları gelmektedir. Araştırma bulgularına göre maliyetin en düşük olduğu grubun ise inek sütü grubu olduğu gözlemlenmiştir. Temin edilmesi kolay olan inek sütü, yapay büyütme yönteminde maliyeti düşürmek için tercih edilebilecek bir sıvı yem olarak ortaya çıkmaktadır.

\section{TARTIŞMA}

Araştırmada elde edilen bulgulara göre farklı süt ve süt ikame yemlerinin, oğlakların doğumlarından sonraki ilk on beş günlük dönemdeki canlı ağırlıklarını önemli derecede etkilediği bulunmuştur $(P<0.05)$. Bu dönemde kuzu süt ikame yemi grubundaki oğlakların diğer deneme gruplarından daha fazla gelişim gösterdiği saptanmıştır. Ayrıca tüm grupların bu yaş dönemi incelemelerinde istatistiksel olarak inek sütü grubu diğer deneme gruplarından farkı önemli bulunmuştur $(P<0.05)$. İnek sütü grubunun diğer gruplardan düşük gelişim gösterdiği anlaşılmıştır. Bunun nedeni, inek sütünün yağ ve protein oranının diğer sıvı besinlere göre düşük kalması olarak yorumlanmıştır. Doğum sonrası erken dönemde oğlaklar sadece sıvı besin tükettiği için sıvı besinlerin besin değeri canlı ağırlık artışları için çok önemlidir. Bu dönemde kaba ve kesif yem tüketimleri arasındaki farklılıklar istatiksel olarak önemsiz bulunmuştur $(\mathrm{P}>0.05)$. Bu alanda yapılan diğer çalışmalarda, Delgado-Pertinez ve ark., 2009' da keçi sütü ve süt ikame yemi gruplarında sırasıyla ortalama canlı ağırlıkları; 5.35 ve 4.95 kg olarak saptamışlardır. Ayrıca yapılan diğer çalışmalarda da yakın değerlerde canlı ağırlık ve günlük canlı ağırlık artış değerlerini bulan araştırmalar da bulunmaktadır (Galina, 1995; Demirören ve ark, 1999; Çağraş ve ark. 1999; Delgado ve ark., 2009). Saanen oğlaklarında on beş günlük ortalama canlı ağırlık değerleri yükseltilmesi, büyütme için kullanılan sıvı besinlerin içeriğinin keçi sütü değerine yakın olmasına bağlı olduğu düşünülmektedir. Bu dönemde kaba yem tüketimi en az değerlerde olduğundan dolayı oğlaklar eksik kalan besin intiyaçlarını karşılayamamaktadırlar. Ancak oğlakların rumen gelişimi başladıktan sonra kaba ve kesif yem tüketimi artarak canlı ağırıklar arasındaki farklar azalmaktadır.

Araştırma kapsamında otuzuncu günlük yaşta gruplardan elde edilen bulgular incelendiğinde canlı ağırlık ortalamaları; keçi ve inek sütü gruplarının süt ikame yemi gruplarından istatiksel olarak farkının önemli olduğu belirlenmiştir $(P<0.05)$. Keçi ve inek sütü, kuzu, buzağı ve oğlak süt ikame yemleri gruplarının canlı ağırlık ortalamaları sırasıyla; 8.31, 7.81, 7.59, 6.99 ve 6.97 kg'dır. Demirören ve ark. (1999) inek sütü ile büyütülen oğlaklarda, otuzuncu gün ortalama canlı ağırlıkları 8.67 kg olarak bulmuşlardır. İki çalışmadaki ağırlıklar arası bu fark ele alınan çalışmada inek sütünün ad-lib şekilde oğlaklara verilmesinden kaynaklandığı düşünülmektedir. Sonuçlara göre on beş ile otuzuncu gün arasında gruplar arası ortalama canlı ağırlık artışları incelendiğinde keçi sütü, inek sütü, kuzu ve oğlak süt ikame yemleri grupları ile buzağı süt ikame yemi grubu arasında istatiksel açıdan fark önemli bulunmuştur $(P<0.05)$. Canlı ağırlık artış ortalamaları sırasıyla; $177.78,179.17,162.92,144,57$ ve 119.47 g'dır. Doğal sütler olan keçi ve inek sütü ile süt ikame yemleri arasında canlı ağırlık açısından farkların 
oluşması rumen gelişiminin hızından kaynaklanabileceği düşündürmektedir. Doğal sütlerde rumen gelişimi daha hızlı olduğu ve bunlarla büyütülen oğlaklarda selülozlu yemlerden yararlanmanın daha hızlı olduğu anlaşıımaktadır. Gruplardan elde edilen kaba ve kesif yemin tüketim miktarları incelendiğinde keçi ve inek sütü grupları ile kuzu, buzağı ve oğlak süt ikame yemleri grupları arasında kaba ve kesif yem tüketimleri farkı istatiksel açıdan önemli bulunmuştur $(P<0.05)$. Kaba yem tüketimleri sırasıyla $24.7,26.0,16.5$, 19.7 ve $17.9 \mathrm{~g}$ bulunmuş, kesif yem tüketimleri 45.1, 45.1, 32.7, 27.7 ve $27.5 \mathrm{~g}$ bulunmuştur. Yapılan çalışmalarda gözlenen sınırlı miktarda sıvı besin tüketen oğlakların doğal süt kullanımı, süt ikame yemi kullanımından daha hızlı şekilde rumen gelişimini sağladığı ortaya konmuştur(Davis ve ark., 1998, Sampeloyo ve ark., 1990).

Araştırmada kırk beşinci günlük yaştaki oğlak gruplarından elde edilen bulgular incelendiğinde canlı ağırlık ortalamaları; bu yaş döneminde besin değeri yüksek olan kuzu ve oğlak süt ikame yemi gruplarının ruminal gelişimleri hızlanmış ve doğal süt gruplarıyla canlı ağırlık ortalaması açısından eşitlenme noktasına gelmişlerdir. Ancak buzağı süt ikame yemi grubunun ruminal gelişiminin diğer gruplara göre geride kaldığı anlaşılmaktadır. Bu grupta kesif yem tüketiminin diğer gruplara göre daha az olduğu saptanmıştır. Ancak kuzu, buzağı ve oğlak süt ikame yemi grupları arasında kaba ve kesif yem tüketimleri farkı istatiksel açıdan önemli bulunmamıştır $(P>0.05)$. Bu dönemde, doğal süt grupları ile süt ikame yemi grupları arasında kaba ve kesif yem tüketimleri farkı istatiksel açıdan önemli bulunmuştur $(\mathrm{P}<0.05)$. Günlük kaba yem tüketimleri sırasıyla $50.0,52.7,32.8,41.1$ ve $38.5 \mathrm{~g}$ bulunmuş ve günlük kesif yem tüketimleri $64.2,66.5,54.1,50.5$ ve $55.0 \mathrm{~g}$ bulunmuştur.

Araştırmada sütten kesim dönemi bulguları incelendiğinde grupların canlı ağırlık ortalamaları arasındaki fark istatiksel olarak önemli bulunmuştur $(P<0.05)$. Keçi ve inek sütü, kuzu, buzağı ve oğlak süt ikame yemleri gruplarının canlı ağırlık ortalamaları sırasıyla; $14.12,13.80,13.72,12.73$ ve $13.41 \mathrm{~kg}$ olarak saptanmıştır. Çalışmada elde edilen sonuçlara göre son on beş günün gruplar arası günlük canlı ağırlık artış ortalamaları sırasıyla; 166.27, 187.94, 206.47, 202.01 ve $210.47 \mathrm{~g}^{\prime}$ dır. Sütten kesim döneminde grupların günlük kaba yem tüketimleri sırasıyla 77.4, $75.2,54.0,54.3$ ve $52.8 \mathrm{~g}$ bulunmuş ve günlük kesif yem tüketimleri 157.2, 163.6, 86.4, 84.8 ve $88.5 \mathrm{~g}$ olduğu saptanmıştır. Yapılan çalışmada gözlenen sınırlı miktarda sıvı besin verilen oğlaklarda doğal süt kullanımı, süt ikame yemi kullanımından daha hızlı şekilde rumen gelişimini sağladığı gözlenmiştir. Bu oğlakların kaba ve kesif yem tüketim miktarları daha fazla olduğu belirlenmiştir.

Araştırma kapsamında büyütülen oğlakların, birim canlı ağırlıklarının maliyeti keçi sütü grubunda oldukça yüksek bulunurken süt ikame yemi gruplarında birbirlerine oldukça yakın değerler bulunmuştur. İnek sütü grubunun birim maliyet açısından diğer gruplara göre oldukça düşük olduğu belirlenmiştir. Keçi ve inek sütü, kuzu, buzağı ve oğlak süt ikame yemleri gruplarının 60 günlük büyütme dönemi boyunca $1 \mathrm{~kg}$ oğlak maliyeti sırasıyla; $7.75,4.28,6.66,6.38$ ve $6.23 \mathrm{TL}$ olarak hesaplanmıştır. Keçi sütü grubunun maliyetinin bu kadar yüksek olması 1 It keçi sütünün fiyatının veya parasal değerinin diğer sıvı besinlerden daha yüksek olmasından kaynaklanmasıyla açıklanabilir. Gruplarda büyütülen oğlakların sütten kesim sonrası bireysel maliyetleri incelendiğinde sırasıyla; 131.14, 72.66, $102.96,93.19$ ve 98.17 TL olarak hesaplanmıştır. Gelişim ve maliyet oranı açısından büyütmede kullanılan sıvı besinler arasında inek sütü grubunun diğer deneme gruplarına göre daha iyi performans sağladığı belirlenmiştir. İnek sütünün oğlakların büyütülmesinde kullanılmasında asitlendirilerek tükettirilmesi işçiliğin azalması açısından oldukça önem kazanmaktadır (Davis ve ark., 1998). Ancak hayvan kapasitesi yüksek olan işletmelerde yeni geliştirilen otomasyon sistemleriyle süt ikame yemi kullanılması daha yararlı olacaktır. Süt ikame yemi seçiminde ise maliyet ön plana alınarak tercihler yapılmalıdır. Bu çalışmada, Avustralya' dan ithal edilen Saanen oğlaklarında yapay büyütme yöntemi uygulayarak, keçi sütü, inek sütü, kuzu, buzağı ve oğlak süt ikame yemlerinin, büyüme performanslarına etkileri incelenmiştir. Sütten kesilen oğlaklarda sütten kesim ağırlığı istatiksel olarak buzağı süt ikame yemi grubunda farklı bulunsa da çalışmadaki tüm sıvı besinlerin oğlak büyütmede rahatlıkla kullanılabileceği anlaşılmaktadır. Keçi işletmesine sahip olan yetiştiriciler imkânları doğrultusunda, oğlaklarının sağlığını ve gelişimlerini olumsuz yönde etkilemeyecek bu sıvı besinlerden, erişilebilirliği kolay olanı, işletmenin kârlılı̆ını göz önüne alınarak oğlakların büyütülmesinde kullanabilecekleri anlaşılmıştır.

Araştırma kapsamında elde edilen bütün bulgular incelendiğinde, dönemlere göre performans açısından gruplar arasında bazı farklılıkların olduğu görülmektedir. Bu farklılıklar oğlakların doğum-sütten kesim dönemi incelendiğinde; keçi sütü, inek sütü, kuzu süt ikame yemi ve oğlak süt ikame yemi grupların ortalamaları arasında önemli düzeyde fark bulunmamıştır. Ancak buzağı süt ikame yemi grubunun, sıvı besininde ham yağ ve proteinin yüzdesel oranın yetersiz olması diğer gruplara göre performansın daha az olmasına 
sebep olmuştur. Bu konuyla ilgili önceden yapılan araştırmaların da bildirdiği gibi Saanen oğlakların 10 kg canlı ağırlığa sahip olanların rahatlıkla sütten kesilebileceği anlaşılmıştır. Yapılan bu araştırmada buzağı süt ikame yemi grubu oğlakların sütten kesim ortalamaları $10 \mathrm{~kg}$ canlı ağırlığı geçebildiği için rahatlıkla oğlakların buzağı süt ikame yemi kullanarak büyütülebilecekleri kanısına varılmıştır. Araştırma sonuçları göre sınırlı verilen tüm sıvı besinlerin, 60 günlük büyütme döneminde oğlakları 10 kg'lık sütten kesim ağırlığına ulaştırdığı belirlenmiştir. Araştırmadaki tüm sıvı besinler, sağlıklı ve gelişmiş oğlak büyütme imkânı sağlamaktadır. Oğlakların gelişmesi yeterli görülen

\section{KAYNAKLAR}

Akyıldız, R., 1984, Yemler bitkisi laboratuvar kılavızu. A. Ü. Ziraat Fakültesi yayınları: 895 .

Alçiçek, A. , 2010, Yeni doğan kuzu ve oğlakların beslenmesinde ağız sütünün (kolostrum) önemi. Birlik Postası 3: 24-26.

Argüello, A., Castro, N. and Capote, J, 2004, Growth of milk replacer kids fed under three different managements. Journal of Applied Animal Research, v.25, p.37-40.

Argüello, A., Castro, N. and Capote, J., 2007, The influence ofartifici al rearing and live weight at slaughter on kid carcass characteristics. Journal of Animal and Veterinary Advances, $6(1): 20-25$.

Çağraş, İ., Özçelik, M., Uğur, F. ve Karabayır, A., 1999, Farklı iki sürüde sütten kesilen Saanen oğlaklarının büyüme özellikleri, Uluslararası Hayvancılık Kongresi Kitabı; 789-792

Davis, J. J., Sahlu, T., Puchala, R. and Tesfai, K., 1998, Performance of Angora Goat Kids Feed Acidified Milk Replacer at Two Levels of İntake. Small Ruminant Research. 28(3): 249-255.

Diken, F., 2005, "Farklı Emzirme Programlarının Saanen Oğlaklarının Büyüme Özellikleri Üzerine Etkileri ”, Çanakkale Onsekiz Mart Üniversitesi, Yüksek lisans tezi.

Diken, F., F. Uğur, C. Tölü, and M.D. Akbulut, 2008, "Effects of Suckling Schedule on Growth Characteristics of Saanen Kids" Archiv fur Tierzucht- Archives of Animal Breeding, 51(1): 55-63.

Delgado-Pertinez, M., Guzman-Guerrero, J.L., Mena, Y., Castel, J.M., Gonzalez-Redondo, P., Caravaca, F.P. 2009. Influence of kid rearing systems on milk yield, kid growth and cost of Florida dairy goats. Small Rumin. Res. 81: 105-111.

Demirören, E., Taşkın, T., Alçiçek, A. ve Koşum, N., 1999. İnek sütü ile emiştirilen oğlaklarda gelişme, Ege Üniversitesi Ziraat Fakültesi Dergisi, 36: 1-3.

Ertuğrul, M., 1997, Keçi Yetiştirme. Hayvan Yetiştirme (Yetiştiricilik Ders Kitabı), (Ed. M.Ertuğrul). Baran ofset.

FAO, 2012. Food and agriculture organization statistical databese, http://faostat.fao.org/ Erişim Tarihi: 03.06.2015.

FAO, 2013. Food and agriculture organization statistical databese, http://faostat.fao.org/ Erişim Tarihi: 03.06.2015.

Galina, M. A., Palma, J. M., Pacheca, D. and Marcles, R., 1995, Effect of Goat Milk, Cow Milk, Cow Milk Replacer and Pratical Substituon of Replacer Mixture with whey on Artificial Feeding of Femele Kids. Small Ruminant Research.17: 153-158. tüm sıvı besinlerde büyütme maliyetlerine göre sıvı besin seçimi yapılmalıdır. Böylelikle daha fazla kazanç elde edilirken aynı zamanda sağlıklı oğlaklar büyütülebilmektedir.

\section{TEŞEKKÜRLER}

Bu çalışma, Ege Üniversitesi Bilimsel Araştırma Projesi Şube Müdürlüğü (BAP) tarafından 2011 ZRF 070 nolu proje kapsamında desteklenmiştir. Çalışmaya maddi desteğinden dolayı Ege Üniversitesi Bilimsel Araştırma Projeleri Şube Müdürlüğüne teşekkür ederiz.

Genandoy, H., Sahlu, T., Davis, J., Wang, R. J., Hart, S. P. Puchala, R. and Goetsch, A.L., 2002, Effects of Different Feeding Methods on Growth and Harvest Traits of Young Alpine Kids. Small Ruminant Research. 44: 81-87.

Gürbüz, F., E. Başpınar, H. Çamdeviren ve S. Keskin. 2003, Tekrarlanan ölçümlü deneme düzenlerinin analizi, Yüzüncü Yil Üniversitesi Matbaası, Van.

Kaymakçı, M., 2006, Keçi Yetistiriciligi. 238s. Bornova.

Keskin, M. ve Biçer, O., 2001, Effects of Milk Replacer on Kid Growth and Farm Profitability in The Shami Goat. Turkish Journal of Veterinary and Animal Science. 26, 1133- 1136.

Koşum, N.: Alçiçek, A.: Taşkın, T.: Önenç, A., 2003, Fattening performance and carcass characteristics of Saanen and Bornova male kids under an intensive management system. Czech Journal of Animal Science 48 (9):379-386.

Koyuncu, E., Pala, A., Savaş, T., Konyalı, A., Ataşoğlu, C., Daş., G., Ersoy, İ. E., Uğur, F., Yurtman, İ.Y. ve Yurt, H.H., 2005, Çanakkale koyun keçi yetiştiricileri birliğine üye keçi yetiştiriciliği yapan işletmelerin teknik analizi. Süt Keçiciliğ Ulusal Kongresi 26-27 Mayıs, İzmir.

Sampelayo, M. R. S., Hernandez, O. D., Naranjo, J. A., Gill, F. and Boza, J., 1990, Utilisation of Goat Milk vs. Milk Replacer for Grandina Goat Kids. Small Ruminant Research. 3:37-46.

Savaş, T., 2007, Oğlak Büyütme: Sorunlu Noktalar Üzerinde Bir Değerlendirme, E.Ü. Hayvansal Üretim 48(1): 44-53,

Şengonca, M., 1989, Küçükbas Hayvan Yetistirme 1. Bölüm (Keçi Yetistirme) U.U. Güçlendrme Vakfı N:27 Bursa.

SPSS, 2007. SPSS 15 for windows. SPSS Inc

Tacchini , F., Rebora C., S. Van Den Bosch, A. Gasc'on M. and Pedrani, 2006, Formulation and testing of a whey-based kid goat's milk replacer Small Ruminant Research 63 : 274-281

Türkiye İstatistik Kurumu Veritabanları, 2014, Hayvanc1lk İstatistikleri, http:www.tuik.gov.tr. Erişim Tarihi: 03.06.201.

Uğur, F., Savaş, T., Daş, G., Mendeş, M. ve Diken, F., 2005, Farklı iki emzirme programına göre süt içerek büyütülen genç Saanen keçilerin süt verimi özellikleri. Süt Keçiciliği Ulusal Kongresi, 26-27 Mayıs, İzmir.

Umberger, H.S., 1997, Profitable artificial rearing of lambs. Animal and Poultry Science, Publication No. 410-023. Virginia Cooperative Extension. 